\title{
Distribution Patterns of Place-Name Pronunciations ${ }^{1}$
}

\section{HAROLD B. ALLEN}

T

HIS ARTICLE will support an obvious generalization with new evidence. It will pinpoint the general knowledge possessed by every traveler who has gone from here to there - from [teksen] to [tusán] "Tucson," from [lə jálə] to [la həyə] "La Jolla," from [pićr] to [pir] "Pierre," South Dakota, from [bítrəs] to [biǽtrəs] "Beatrice," Nebraska, from [bəIz] to [borzi] "Boise," Idaho, or from [mǽkənæk] to [mǽkənə] "Mackinac" Island, Michigan. It is simply the general knowledge that local residents constitute their own supreme court in determining the pronunciation of their own community, and that as a traveler approaches that community he finds learned pronunciations and spelling pronunciations giving way in the face of the ineluctable force of the native speech.

Evidence for this pinpointing is taken from the field records of the The Linguistic Atlas of the Upper Midwest, one of the independent but correlated projects within the framework of the The Linguistic Atlas of the United States and Canada. It includes Minnesota, Iowa, both Dakotas, and Nebraska. The records were made in close phonetic transcription by trained fieldworkers, who in these five states interviewed 208 selected informants who were lifelong residents of their communities. These informants fall into three groups: Type I, old-fashioned with no more than 8 th grade schooling; Type II, middle-aged with high school training; Type III, forty-ish with college education obtained within the state.

For a number of reasons, as the accompanying list indicates, a number of place-names were included among the 807 items in the fieldworker's questionnaire. A few of these provide evidence indicating a consistency in the variation of place-name pronunciation distinctions.

\footnotetext{
1 This article is based upon a paper read before the American Name Society in Madison, Wisconsin, September 10, 1957.
} 
One important Upper Midwest city provides a typical example - Des Moines, Iowa. Chart 1 shows that $96 \%$ of the informants interviewed in Iowa use the form without the terminal sibilant, a pronunciation surely derived from the original French. In Nebraska the proportion is somewhat less, $83 \%$; and it is still less in the Dakotas. Minnesota, with little influx of Iowa population, shows still weaker Iowa effect and much stronger influence of spelling pronunciation. Two-thirds of the Minnesotans use the pronunciation [de móynz] and only one-third that without the final [-z]. Once only, and that in the speech of a Canadian informant farthest of all informants from Iowa, did I hear the full spelling pronunciation [des móynz].

Omaha, Nebraska, provides a similar pattern. The several variant spoken forms of this place-name reveal a range for the final vowel from no liprounding and low central position to full rounding and higher low back position, that is, from [a] to [0], with the intermediate $[d]$ and $[b]$ also occurring. It is the full rounded [0] which reveals a consistent pattern. Omaha, it may be observed, is the trade center for western Iowa and nearly all of Nebraska. In these two states 45 and $39 \%$ of the informants, respectively, use the full rounded [o]. If Omaha were spelled Omahaw, probably this pronunciation would be common elsewhere, too, for it would suggest more readily the rounded vowel. (Compare pronunciations of Pawpaw, Kenesaw, Choctaw, etc.) But the final single $a$ leads to a spelling pronunciation with [a] or [d] so common that competing [0] has an incidence of only $16 \%$ in South Dakota and $12.5 \%$ in North Dakota. Because the item was added late during the fieldwork in Minnesota, the evidence there is meager. Only six informants in or near the Twin Cities were asked for the term; not one uses [0].

Comparable evidence is found in the data for several names of places or areas close to the Upper Midwest. Chicago is an example, although here particularly the recourse to percentages is necessary to reveal the pattern. No drawing of isophones upon a map can show this gradual distribution. In Iowa, closest Upper Midwest state to Chicago, $78 \%$ of the informants use the low back rounded [0] in the stressed syllable instead of the unround low central [a]. But the spelling pronunciation with [a] is more frequent where the Illinois influence is more distant; only $58 \%$ of the Minnesota informants, for example, use the rounded form as in [šrkógo]. 
The name of the state itself offers another case in point. It is well known that two pronunciations exist for Illinois, one with and one without the final [-z]. Cabell Greet in his World Words lists both without comment; Kenyon and Knott in their Pronouncing Dictionary of American English remark that [Ilənórz] is not infrequent generally but is especially common in the South. The Upper Midwest data offer additional light. In Iowa, separated from Illinois only by the Mississippi river and close culturally and ethnically likewise, $90 \%$ of the informants use the traditional and historical [Ilənor]. But farther away the French derived final $-s$ is accorded value as a sound symbol, so that in North Dakota, for instance, only $62 \%$ of the informants use the historical pronunciation; the rest follow the spelling with [Ilənórz].

But just as Grimm's law has its necessary footnote in Verner's law, so the generalization stated at the beginning of this paper has its exceptions to be explained by another principle. The influential element of distance may be counteracted by a prestige factor, as with the name Missouri. In World Words Greet says: "American Speech once printed an article of 17 pages on the pronunciation of this name. My impression is that three out of four Missourians" favor the pronunciation [mIzúrə] but that the fourth preferring [mIzúri] regards it as socially superior. This estimate is now borne out by Upper Midwest evidence. In Iowa, contiguous with Missouri, $65 \%$ prefer the [mIzúre] form, and in Nebraska, also a neighbor, $58 \%$ prefer it. Farther away in Dakotas, as one would expect according to the basic principle, the spelling pronunciation has won out; [mIzúrə] drops to $21 \%$ in North Dakota and $17 \%$ in Minnesota. But if the returns are analyzed in terms of the types of informants, then a significant contrast shows up. Although three out of four educated Iowans favor [- - ], the college graduates generally in these five states prefer the prestigious form with [-I], the proportion being $64 \%$ even with Iowa included.

A prestige factor operates also with the form [árəwə]. The historical form is [árəwe], but this pronunciation is now looked upon by many as old-fashioned and rural. It is retreating even in Iowa itself, where this attitude is re-enforced by pressure from the schools. Whereas $54 \%$ of the oldest generation informants still use [árəwe], only $15 \%$ of the high school graduates use it, and none of the college graduates (except, presumably, when they sing the state 
song!). Similarly in Nebraska, next to Iowa. In South Dakota the older relationship is better preserved, with a much higher proportion favoring the historical form. But in Minnesota, never greatly influenced by Iowa speech, the spelling pronunciation is preferred by all three types of informants, although here, as in the other states, the uneducated informants do show a higher proportion favoring [áIəwe]. Since no members of the younger generation are reported as using this form, it would seem safe to predict its disappearance within the next two generations.

The evidence in this article, though not startling, may help to confirm beliefs about the reasons for the changing of form of placenames and hence may be of value in the reconstruction of earlier forms. Additional evidence, as yet not analyzed, lies in the data for other place-names recorded by field investigators for the various American regional atlases.

University of Minnesota. 

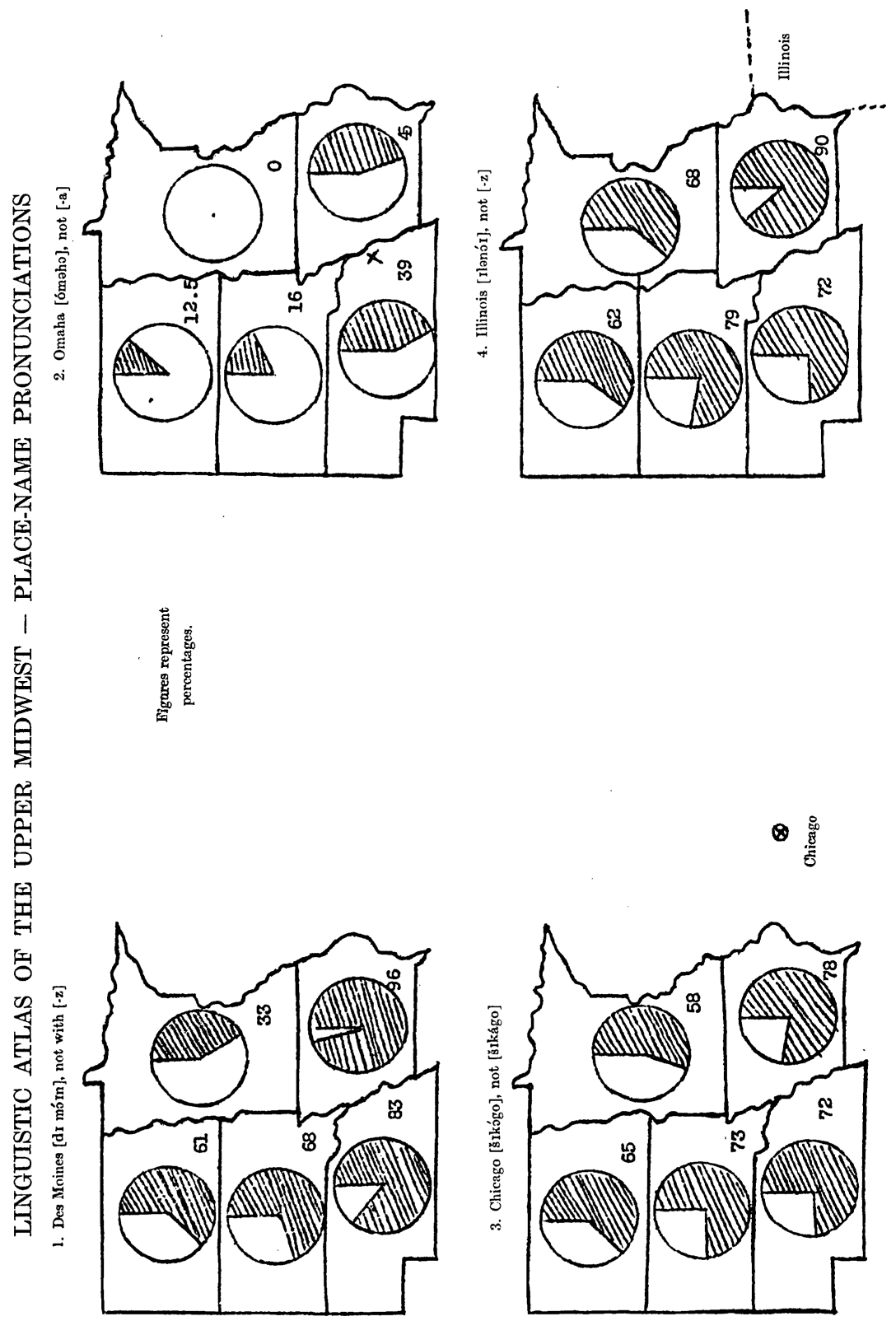

Q $\frac{8}{8}$

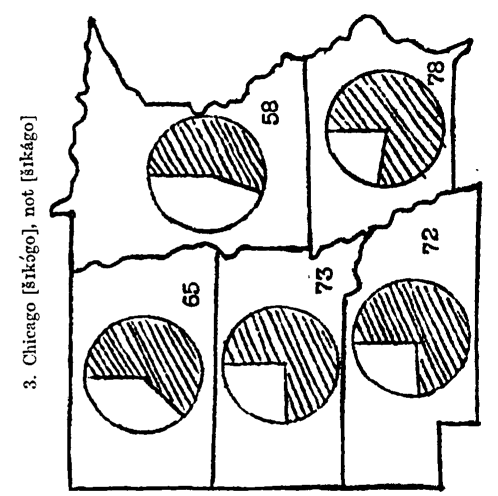




\section{LAUM - PLACE-NAME PRONUNCTATIONS}

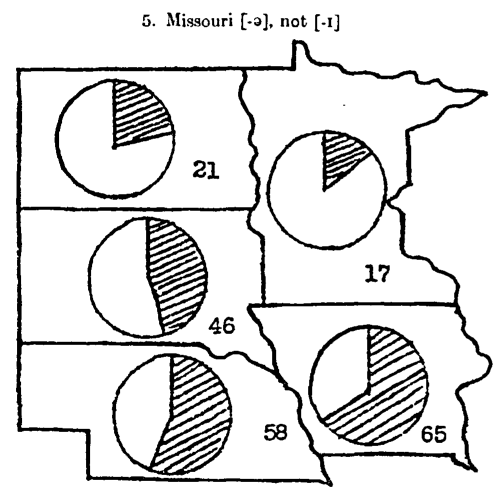

6. Iowa [á Iəwe], not [á Iəwə]

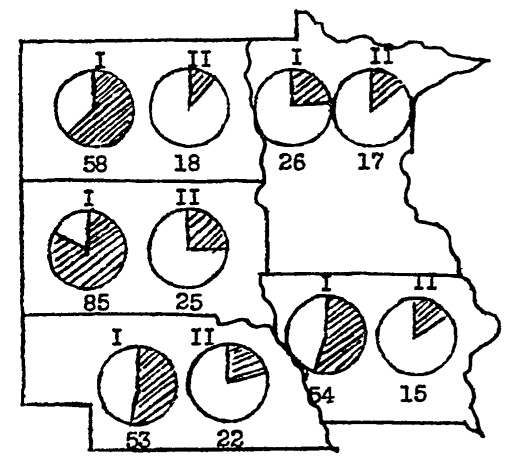

Place-names phonetically transcribed during fieldwork for the Linguistic Atlas of the Upper Midwest:
Michigan
Illinois
Ohio
Dakota
New York
Pennsylvania
Iowa
Minnesota
Wisconsin
Canada
Nebraska
Missouri
Chicago
St. Paul
Des Moines
Detroit
Duluth
Omaha
Minneapolis
Washington

the informant's own community (also names of rivers and streams within a few miles of the informant's community) 